\title{
Phylogenetic diversity of rhizobial strains nodulating Robinia pseudoacacia L.
}

\author{
Andreas Ulrich ${ }^{1}$ and Irmtraut Zaspel ${ }^{2}$
}

\begin{abstract}
1 ZALF - Centre for Agricultural Landscape and Land Use Research, Institute of Primary Production and Microbial Ecology, Eberswalder Str. 84, D-15374 Müncheberg, Germany

2 Federal Research Centre for Forestry and Forest Products, Institute for Forest Genetics and Forest Tree Breeding, Eberswalder Chaussee 3, D-15377 Waldsieversdorf, Germany
\end{abstract}

Author for correspondence: Andreas Ulrich. Tel: +4933432 82345. Fax: +49 3343282344. e-mail: aulrich@zalf.de

Lack of knowledge exists regarding the diversity of rhizobial strains nodulating black locust (Robinia pseudoacacia L.), which is a neophytic tree species widely distributed in Europe. Seventeen rhizobial strains isolated from nodules of black locust at a German location were examined by phenotypic characterization and 165 rDNA analysis. The isolates were classified in nine 16S rDNA genotypes using a set of seven endonucleases. Based on RFLP analysis and sequencing, the strains were shown to belong to the genera Mesorhizobium (76\%) and Rhizobium (24\%). Five genotypes were identical to the species Mesorhizobium amorphae, Mesorhizobium loti, Mesorhizobium huakuii, Rhizobium leguminosarum and Rhizobium tropici. A strong similarity between the 165 rDNA sequence of another two genotypes and $M$. amorphae $(99.9 \%)$ as well as the Mesorhizobium strain R88b $(99.8 \%)$ was found. The two remaining genotypes were classified in the genus Rhizobium, without a significant relationship at the species level. Comparing isolates nodulating Rob. pseudoacacia and Amorpha fruticosa, a parallel picture of phylogenetic diversity was detected with a range of phylogenetically different rhizobia and M. amorphae dominating. For this study, 18 rhizobial strains which had originally been isolated from a forest in Maryland where black locust is native were additionally analysed. Results revealed seven genotypes all belonging to the genus Mesorhizobium, with four genotypes identical to the isolates from the German sampling location. Whereas the genotype identical to $M$. amorphae dominated within the strains obtained from the German location, the dominance of a genotype identical to $M$. huakuii was found among the strains from the native location. Summarizing data from both locations, Rob. pseudoacacia was nodulated with various genomic species, most of which belonged to the genus Mesorhizobium. Concerning phenotypic features such as growth rate, pH tolerance or use of certain carbohydrates, most isolates corresponded to described species and genera. However, there were differences in salt tolerance between these isolates and the corresponding reference strains. Overall, the results demonstrated a high phenotypic and phylogenetic diversity of rhizobial strains nodulating Rob. pseudoacacia. This may be a characteristic of neophytic and other widely spread legumes and may contribute to the success of black locust as a pioneer tree species for the temperate zone.

Keywords: Mesorhizobium, Robinia pseudoacacia, black locust, 16S rDNA sequences, PCR-RFLP

\section{INTRODUCTION}

Black locust (Robinia pseudoacacia L.) originated from

The EMBL accession numbers for the sequences reported in this paper are AJ271898-AJ271902 for the Mesorhizobium strains Rob6, Rob8 and Rob23 and the Rhizobium strains Rob18 and Rob20, respectively.
North America but is gaining more and more importance in middle Europe as a fast-growing tree species suitable for the afforestation of arable land and devastated areas with former mining activity. The tree is characterized by good growth on poor and nitrogendeficient soils, resistance to wood-destroying organisms and a high wood quality, which is of increasing interest 
to the timber industry. Consequently, breeding strategies that included plant tissue culture methods were developed for the cultivation of selected phenotypes with straight-growing trunks (Hanover, 1992). Experiences with micropropagation of selected cultivars and clones for mass production were reported by several authors (Gruber \& Hanover, 1992). However, the process of micropropagation of black locust is difficult compared to other fast-growing deciduous tree species. Besides other problems in cultivation, the lack of rhizosphere micro-organisms on in vitro plantlets led to a high mortality rate under greenhouse conditions. The promotion of growth and especially the rooting ability of plantlets as well as acclimation of young plants derived from tissue culture is possible by inoculation with effective rhizobial strains (Balla et al., 1998; Herrera et al., 1993). Previous investigations of rhizobial strains nodulating black locust demonstrated a high variability in their nitrogen-fixing efficiency, biochemical properties and in the promotion of increased plant biomass (Hoffmann, 1964; Batzli et al., 1992; Han, 1996). On the other hand, the knowledge of phenotypic features and phylogenetic classification of rhizobial strains nodulating black locust under temperate conditions is sparse in comparison to what is known about rhizobia infecting herbaceous plants.

Comparison of $16 \mathrm{~S}$ rDNA nucleotide sequences can be applied for classification of isolates at species and higher levels (Woese, 1987; Cilia et al., 1996). Such phylogenetic analyses of representative rhizobial strains revealed that rhizobia are polyphyletic, and resulted in a reclassification of bacteria able to nodulate legumes into five genera (Young \& Haukka, 1996; Chen et al., 1988; de Lajudie et al., 1994; Dreyfus et al., 1988; Jarvis et al., 1997; Jordan, 1982). The data also confirm that there is no branch of the evolutionary tree exclusively consisting of rhizobial species (Young, 1996). Variations in the 16S rRNA gene sequences have been used for differentiation and classification of numerous rhizobial strains. These studies demonstrated that some legume species were infected by more than one species of rhizobia (Amarger et al., 1994, 1997; Laguerre et al., 1993; Lafay \& Burdon, 1998). However, no strains capable of nodulating black locust were included in these phylogenetic studies. Our objective was to analyse phenotypic features and variation in $16 \mathrm{~S}$ rRNA genes of rhizobial strains promoting growth of black locust plantlets.

\section{METHODS}

Isolation of rhizobia and growth conditions. Most isolates were obtained from nodules of in vitro propagated young plants of Rob. pseudoacacia var. rectissima grown for 2-3 years in the nursery of Waldsieversdorf, Germany. Three other isolates came from 80 -year-old trees of this variety (Rob19, Rob25) or from a natural regenerated young plant (Rob16) grown in a stand located near the nursery. The strains Rob17, Rob18 and Rob20 were isolated from trees of Rob. pseudoacacia var. rectissima ROKO, Rob. pseudoacacia var. monophylla and Rob. pseudoacacia cv. 'Casque rouge' also grown in the nursery. The site belongs to the forest vegetation type of the central Brandenburg pine (linden)-sessile oak area. The mean annual temperature is $8.2{ }^{\circ} \mathrm{C}$; the mean annual precipitation amounts to $520 \mathrm{~mm}$. The soils are moderately fertile sands (degraded brown earth) without connection to groundwater.

Nodules with pink- or red-stained tissue were taken from the root system at a soil depth of about $5 \mathrm{~cm}$. The nodules were surface-sterilized with $0.05 \% \mathrm{AgNO}_{3}$ for $1 \mathrm{~min}$ and washed several times with sterile deionized water (Fox, 1993). The nodule contents were streaked on a glucose medium enriched with pea extract and incubated at $28^{\circ} \mathrm{C}$. The medium contained $\left(\mathrm{l}^{-1}\right) 10 \mathrm{~g}$ glucose, $0.5 \mathrm{~g} \mathrm{~K} \mathrm{HPO}_{4}, 0.5 \mathrm{~g} \mathrm{KH}_{2} \mathrm{PO}_{4}$, $0.2 \mathrm{~g} \mathrm{MgSO}_{4}, 0 \cdot 2 \mathrm{~g} \mathrm{NaCl}, 0 \cdot 1 \mathrm{~g} \mathrm{CaSO}_{4}, 1 \mathrm{mg}\left(\mathrm{NH}_{4}\right)_{2} \mathrm{MoO}_{4}$, $500 \mathrm{ml}$ pea extract (boiled from $100 \mathrm{~g}$ peas) and $15 \mathrm{~g}$ agar adjusted to $\mathrm{pH} 6.8$. Bacteria from single colonies were subcultured on a modified yeast extract-mannitol agar (YMA), which contained $0.5 \mathrm{~g}$ instead of $3 \mathrm{~g}$ yeast extract (Elkan \& Bunn, 1992).

Reference strains. As a reference strain, LMG 4270 (ATCC 10320), isolated from black locust in central Iowa, was used (Thorne \& Walker, 1936). Furthermore, the rhizobial strains USDA 4197, USDA 4207, USDA 4212, USDA 4214, USDA 4222, USDA 4224, USDA 4236, USDA 4242 and USDA 4255 , and USDA 4262, USDA 4279, USDA 4283, USDA 4297, USDA 4313, USDA 4315, USDA 4318, USDA 4322 and USDA 4340, respectively, isolated by Batzli et al. (1992) from black locust trees at two sites in Green Ridge State Forest in Allegany County, MD, USA, were used to characterize the phylogenetic diversity of rhizobia from a native location.

Phenotypic characterization. The growth rates of the 17 isolates were estimated by the incubation time necessary to achieve a colony size of $2-3 \mathrm{~mm}$ on YMA at $28^{\circ} \mathrm{C}$ (Jarvis et al., 1997). Colony colour was examined macroscopically after growth on YMA for $6 \mathrm{~d}$. Carbohydrate utilization was tested in yeast extract-mannitol medium in which mannitol was substituted by inositol or D-raffinose. $\mathrm{NaCl}$ tolerance was determined on YMA containing 5, 7.5, 10 and $12 \cdot 5 \mathrm{~g} \mathrm{NaCl} \mathrm{l}^{-1}$ with three replications. The growth at different $\mathrm{pH}$ ranges was tested in $5 \mathrm{ml}$ yeast extract-mannitol broth adjusted at $\mathrm{pH}$ $5 \cdot 0-9 \cdot 0$ in steps of $0 \cdot 5$ (Batzli et al., 1992; modified). Each broth was inoculated with $200 \mu \mathrm{l}$ of a fresh liquid culture and incubated for $24 \mathrm{~h}$ at $27^{\circ} \mathrm{C}$. The $\mathrm{OD}_{660}$ was measured. For assaying antibiotic resistances, single colonies from 4-d-old cultures were spread on YMA containing either $10 \mu \mathrm{g}$ rifampicin $\mathrm{ml}^{-1}, 25 \mu \mathrm{g}$ nalidixic acid $\mathrm{ml}^{-1}, 50 \mu \mathrm{g}$ kanamycin $\mathrm{ml}^{-1}, 25 \mu \mathrm{g}$ ampicillin $\mathrm{ml}^{-1}, 15 \mu \mathrm{g}$ chloramphenicol $\mathrm{ml}^{-1}$, $30 \mu \mathrm{g}$ streptomycin $\mathrm{ml}^{-1}$ or $15 \mu \mathrm{g}$ oxytetracycline $\mathrm{ml}^{-1}$ (Sigma). The plates were read for growth after $7 \mathrm{~d}$ incubation.

Plant inoculation test. Rooted plantlets of five different genotypes of Rob. pseudoacacia var. rectissima were placed on sterile filter paper saturated with $2 \mathrm{ml}$ sterile water and $1 \mathrm{ml}$ Herridge's plant nutrient solution (Qian et al., 1996) and inoculated with $250 \mu \mathrm{l}$ bacterial suspension of approximately $10^{6}$ cells $\mathrm{ml}^{-1}$. The root system of the plants was covered with moist filter paper, and the dishes were closed with Parafilm strips and cultivated for $30 \mathrm{~d}$ at $23^{\circ} \mathrm{C}$ and $2000 \mathrm{~lx}$ (Philips TLD58W/93). During the first week, the dishes were covered with a thin layer of cellulose to protect green parts of plants against light. The test was performed in triplicate.

PCR amplification. For template preparation, DNA was isolated from bacteria grown on YMA for $2-4 \mathrm{~d}$ at $28^{\circ} \mathrm{C}$. Single colonies were washed with $0.3 \% \mathrm{NaCl}$, resuspended in $20 \mu \mathrm{l} 25 \mathrm{mM} \mathrm{NaOH} / 0.25 \%$ SDS and heated for $15 \mathrm{~min}$ at $95^{\circ} \mathrm{C}$. Aliquots $(0 \cdot 2 \mu \mathrm{l})$ of the resulting lysate were directly 
Table 1. Phenotypic characteristics of isolates nodulating Rob. pseudoacacia

\begin{tabular}{|c|c|c|c|c|c|c|c|c|}
\hline \multirow[t]{2}{*}{ Isolate } & \multirow[t]{2}{*}{ Colony colour* } & \multirow{2}{*}{$\begin{array}{l}\text { Incubation } \\
\text { time }(d)\end{array}$} & \multirow{2}{*}{$\begin{array}{l}\text { Colony diam. } \\
\qquad(\mathrm{mm})\end{array}$} & \multicolumn{3}{|c|}{ Growth } & \multirow[t]{2}{*}{ No. nodules $\dagger$} & \multirow[t]{2}{*}{$\mathrm{AB}^{\mathrm{R}} \neq$} \\
\hline & & & & $\mathrm{pH}$ range & $\begin{array}{l}\text { Max. } \mathrm{NaCl} \\
\text { concn }(\%)\end{array}$ & $\begin{array}{c}\text { Inositol as sole C } \\
\text { source }\end{array}$ & & \\
\hline Rob6 & $\mathrm{p}$ & 5 & $2-4$ & $5 \cdot 5-9 \cdot 0$ & $1 \cdot 00$ & + & $4 \cdot 5^{a b}$ & - \\
\hline Rob8 & $\mathrm{y}$ & 5 & 2 & $5 \cdot 0-9 \cdot 0$ & $1 \cdot 00$ & + & $4 \cdot 4^{a b}$ & $\mathrm{Na}$ \\
\hline Rob9 & $\mathrm{p}$ & 5 & 1 & $5 \cdot 5-8 \cdot 5$ & $1 \cdot 00$ & + & $3 \cdot 9^{a b c}$ & - \\
\hline Rob10 & $\mathrm{p}$ & 5 & $1-2$ & $5 \cdot 5-8 \cdot 5$ & $1 \cdot 00$ & + & $4 \cdot 3^{a b}$ & - \\
\hline Rob11 & $\mathrm{p}$ & 5 & $1-2$ & $6 \cdot 0-8 \cdot 5$ & $0 \cdot 10$ & - & $5 \cdot 4^{a}$ & $\mathrm{Km}$ \\
\hline Rob12 & $\mathrm{p}$ & $5-6$ & $1-2$ & $5 \cdot 5-8 \cdot 0$ & $1 \cdot 00$ & + & $4 \cdot 9^{a b}$ & $\mathrm{Na}$ \\
\hline Rob13 & $\mathrm{p}$ & 5 & $2-3$ & $5 \cdot 5-8 \cdot 0$ & $1 \cdot 00$ & + & $2 \cdot 2^{b c}$ & $\mathrm{Na}$ \\
\hline Rob16 & $\mathrm{p}$ & 5 & $2-3$ & $5 \cdot 5-8 \cdot 5$ & $1 \cdot 00$ & + & $3 \cdot 2^{a b c}$ & $\mathrm{Na}$ \\
\hline Rob17 & $\mathrm{w}$ & 3 & 5 & $5 \cdot 5-8 \cdot 5$ & $0 \cdot 10$ & - & $1 \cdot 6^{c}$ & - \\
\hline Rob18 & $\mathrm{p}$ & 3 & $2-4$ & $5 \cdot 5-8 \cdot 5$ & $1 \cdot 00$ & + & $3 \cdot 3^{a b c}$ & - \\
\hline Rob19 & $\mathrm{p}$ & $3-4$ & $3-4$ & $5 \cdot 5-8 \cdot 0$ & $1 \cdot 00$ & + & $3 \cdot 1^{a b c}$ & - \\
\hline Rob20 & $\mathrm{p}$ & 4 & $2-3$ & $6 \cdot 5-8 \cdot 0$ & 0.75 & - & $4 \cdot 1^{a b c}$ & - \\
\hline Rob21 & $\mathrm{p}$ & 4 & 5 & $5 \cdot 0-9 \cdot 0$ & $1 \cdot 00$ & + & $2 \cdot 8^{a b c}$ & $\mathrm{Na}$ \\
\hline Rob22 & $\mathrm{p}$ & 5 & 3 & $5 \cdot 0-9 \cdot 0$ & $1 \cdot 00$ & + & $3 \cdot 0^{a b c}$ & - \\
\hline Rob23 & $\mathrm{p}$ & 5 & $1-2$ & $5 \cdot 0-9 \cdot 0$ & $1 \cdot 00$ & + & $3 \cdot 2^{a b c}$ & $\mathrm{Na}$ \\
\hline Rob24 & $\mathrm{p}$ & 5 & 2 & $5 \cdot 5-8 \cdot 5$ & $1 \cdot 00$ & + & $3 \cdot 7^{a b c}$ & $\mathrm{Na}$ \\
\hline Rob25 & $\mathrm{p}$ & 5 & 3 & $5 \cdot 5-8 \cdot 5$ & $1 \cdot 00$ & + & $5 \cdot 1^{a}$ & $\mathrm{Na}$ \\
\hline $\begin{array}{l}\text { Rh. leguminosarum } \\
\text { DSM } 30132^{\mathrm{T}}\end{array}$ & $\mathrm{p}$ & $3-4$ & $1-2$ & $5 \cdot 5-8 \cdot 0$ & $1 \cdot 00$ & + & $\mathrm{ND}$ & - \\
\hline Rh. tropici CIAT $899^{\mathrm{T}}$ & $\mathrm{p}$ & 3 & $2-3$ & $5 \cdot 5-8 \cdot 5$ & $2 \cdot 50$ & + & $\mathrm{ND}$ & $\mathrm{Ap}, \mathrm{Na}$ \\
\hline M. loti DSM $2626^{\mathrm{T}}$ & $\mathrm{p}$ & 5 & $1-2$ & $5 \cdot 5-8 \cdot 5$ & 1.50 & + & $\mathrm{ND}$ & $\mathrm{Ap}, \mathrm{Km}, \mathrm{Na}$ \\
\hline M. huakuii DSM $6573^{\mathrm{T}}$ & $\mathrm{p}$ & 6 & $1-2$ & $5 \cdot 5-8 \cdot 5$ & $2 \cdot 50$ & - & ND & $\mathrm{Km}, \mathrm{Na}$ \\
\hline
\end{tabular}

*Colonies were opaque with a pale $(\mathrm{p})$, white $(\mathrm{w})$ or yellowish $(\mathrm{y})$ colour.

† Mean number of nodules obtained after inoculation of 15 black locust plantlets. Different letters denote groups with significantly different numbers of nodules and were determined with the Student-Newman-Keuls test at probability level $\alpha=0 \cdot 05$.

$\ddagger \mathrm{AB}^{\mathrm{R}}$, resistant to the indicated antibiotic. The following antibiotics were screened: $10 \mu \mathrm{g}$ rifampicin $\mathrm{ml}^{-1}, 25 \mu \mathrm{g} \mathrm{nalidixic} \mathrm{acid}(\mathrm{Na}) \mathrm{ml}^{-1}$, $50 \mu \mathrm{g}$ kanamycin $(\mathrm{Km}) \mathrm{ml}^{-1}, 25 \mu \mathrm{g}$ ampicillin $(\mathrm{Ap}) \mathrm{ml}^{-1}, 15 \mu \mathrm{g}$ chloramphenicol ml $\mathrm{m}^{-1}, 30 \mu \mathrm{g}$ streptomycin $\mathrm{ml}^{-1}$ and $15 \mu \mathrm{g}$ oxytetracycline $\mathrm{ml}^{-1}$.

used for PCR without further purification. The primers fD1 and rD1 (Weisburg et al., 1991) used in this study are capable of amplifying almost the entire $16 \mathrm{~S}$ rRNA gene of most eubacteria. For routine assays, a $50 \mu \mathrm{l}$ reaction mixture containing 10 pmol of each primer in a standard buffer (GibcoBRL) was used. The amplifications were performed in a GeneAmp PCR System 2400 (PE Biosystems) with the following protocol: initial denaturation at $95^{\circ} \mathrm{C}$ for $2 \mathrm{~min} ; 30$ cycles of $40 \mathrm{~s}$ at $94^{\circ} \mathrm{C}, 40 \mathrm{~s}$ at $52^{\circ} \mathrm{C}, 1 \mathrm{~min}$ at $72{ }^{\circ} \mathrm{C}$; followed by a single final extension at $72^{\circ} \mathrm{C}$ for $3 \mathrm{~min}$ and a final soak at $4{ }^{\circ} \mathrm{C}$ (Ulrich \& Müller, 1998; modified). After the reaction, aliquots $(3 \mu \mathrm{l})$ of the PCR products were examined electrophoretically in a $1 \%$ agarose gel.

RFLP analysis. PCR products $(2-8 \mu \mathrm{l})$ were digested with each of the following enzymes: CfoI, HaeIII, AluI, HinfI, MspI, Sau3A and ScrFI (Roche Molecular Biochemicals, New England Biolabs). To detect minor differences between bands, the DNA fragments were separated in 2-3.5\% Metaphor agarose gels (FMC Bioproducts) depending on the fragment sizes to be distinguished. The DNA molecular mass markers V and VI were used as size standards (Roche Molecular Biochemicals). The gels were stained with ethidium bromide and documented with a video camera image system (EasyImage plus, Herolab).

Cloning and sequencing. The isolates Rob20, Rob18, Rob6, Rob8 and Rob23 representing genotypes III, IV, V, VI and IX, respectively, were used in $16 \mathrm{~S}$ rDNA sequence determinations. The PCR products obtained after amplification with $P f u$ DNA polymerase (Promega) were purified using the QIAquick PCR purification kit (Qiagen), digested at the HindIII and SalI restriction endonuclease sites within the linker sequence of the primers and subsequently cloned into the vector pSVB30 (Arnold \& Pühler, 1988), which had been digested with the same enzymes. A cycle-sequencing protocol was applied for sequencing both DNA strands with a Li-Cor Sequencer, model 4200 (MWG Biotech), using standard M13 primers. The resulting rDNA sequences of 1436 or 1440 nucleotides, corresponding to the genotypes III and IV, and V, VI and IX, respectively, were analysed for homologies to sequences deposited in the GenBank and EMBL databases. The similarity values were based on a pair-wise comparison of sequences. The determined DNA sequences and various 16S rDNA sequences from selected rhizobial species were aligned using the CLUSTAL w algorithm (program version 1.74; Thompson et al., 1994). The phylogenetic analyses were performed with the PHYLIP computer program package, version 3.55c (Felsenstein, 1993). The neighbour-joining algorithm and the parsimony method were used to generate phylogenetic trees. The neighbour-joining algorithm (Saitou \& Nei, 1987; NEIGHBOR using Bradyrhizobium japonicum as outgroup) was based on a matrix of pair-wise distances corrected for multiple base substitutions by the method of Kimura (1980) (DNADIST with transition/transversion ratio of $2 \cdot 0)$. The parsimony method (DNAPARS) was applied with ten jumbles of the data set. Both trees were constructed using the original data set and 100 bootstrap data sets.

\section{RESULTS}

\section{Phenotypic characteristics}

17 rhizobial strains investigated in this study were isolated from black locust grown in a nursery or nearby woodland located in the north-eastern German pinesessile oak area. All isolates were verified to be rhizobia by inoculation of sterile plantlets from five Rob. 
Table 2. Restriction patterns of amplified $16 \mathrm{~S}$ rDNA of rhizobial strains isolated from black locust and comparison of the resulting $16 \mathrm{~S}$ rDNA genotypes with those of the reference strains

\begin{tabular}{|c|c|c|c|c|c|c|c|c|}
\hline \multirow[t]{2}{*}{ Isolate or reference strain } & \multicolumn{7}{|c|}{ Restriction pattern of amplified $16 \mathrm{~S}$ rDNA digested with :* } & \multirow{2}{*}{$\begin{array}{l}\text { 16S rDNA } \\
\text { genotype }\end{array}$} \\
\hline & $A l u \mathrm{I}$ & $C f o I$ & HaeIII & HinfI & MspI & Sau3A & ScrFI & \\
\hline Rob19, Rh. leguminosarum DSM 30132 & a & a & a & a & a & a & a & I \\
\hline Rob17, Rh. tropici CIAT $899^{\mathrm{T}}$ & a & $\mathrm{b}$ & a & a & $\mathrm{b}$ & a & b & II \\
\hline Rob 20 & $\mathrm{x}$ & a & $\mathrm{b}$ & $\mathrm{b}$ & $\mathrm{a}$ & $\mathrm{b}$ & $\mathrm{x}$ & III \\
\hline Rob 18 & $\mathrm{y}$ & $\mathrm{y}$ & $\mathrm{b}$ & $\mathrm{b}$ & y & $\mathrm{y}$ & $\mathrm{y}$ & IV \\
\hline $\begin{array}{l}\text { Rob6, Rob9, Rob10, Rob13, Rob22, LMG 4270, } \\
\text { USDA 4255, USDA } 4207\end{array}$ & c & d & a & e & $\mathrm{x}$ & $\mathrm{e}$ & c & $\mathrm{V}$ \\
\hline Rob8, Rob12, Rob16 & c & $\mathrm{d}$ & a & $\mathrm{d}$ & $\mathrm{x}$ & e & c & VI \\
\hline Rob21, M. loti DSM $2626^{\mathrm{T}}$ & c & $\mathrm{d}$ & a & $\mathrm{e}$ & e & $\mathrm{e}$ & c & VII \\
\hline $\begin{array}{l}\text { Rob11, Rob25, M. loti DSM 5235, M. huakuii } \\
\text { DSM 6573T, USDA 4212, USDA 4214, USDA 4224, } \\
\text { USDA 4242, USDA 4262, USDA 4279, USDA } 4283 \text {, } \\
\text { USDA 4313, USDA } 4340\end{array}$ & $\mathrm{c}$ & g & a & g & $\mathrm{j}$ & e & c & VIII \\
\hline Rob23, Rob24, USDA 4222, USDA 4315, USDA 4318 & c & g & a & $\mathrm{g}$ & e & e & c & IX \\
\hline USDA 4197 & c & $\mathrm{d}$ & a & $\mathrm{d}$ & $\mathrm{x}$ & $\mathrm{x}$ & c & \\
\hline USDA 4236 & c & $\mathrm{d}$ & a & $\mathrm{g}$ & $\mathrm{j}$ & e & c & \\
\hline Rh. etli CFN $42^{\mathrm{T}}$ & a & a & $\mathrm{b}$ & $\mathrm{b}$ & a & $\mathrm{b}$ & $\mathrm{a}$ & \\
\hline M. loti DSM 2627, USDA 4322 & $\mathrm{c}$ & $\mathrm{g}$ & a & $\mathrm{h}$ & $\mathrm{j}$ & e & c & \\
\hline Mesorhizobium ciceri DSM $11540^{\mathrm{T}}$ & $\mathrm{c}$ & $\mathrm{d}$ & a & $\mathrm{d}$ & e & e & c & \\
\hline Mesorhizobium mediterraneum DSM $11555^{\mathrm{T}}$ & c & g & a & $\mathrm{d}$ & $\mathrm{x}$ & e & c & \\
\hline M. tianshanense DSM $11417^{\mathrm{T}}$, USDA 4297 & $\mathrm{z}$ & $\mathrm{z}$ & $\mathrm{z}$ & $\mathrm{b}$ & $\mathrm{z}$ & e & y & \\
\hline Sinorhizobium fredii DSM $5851^{\mathrm{T}}$ & a & a & a & $\mathrm{d}$ & $\mathrm{d}$ & $\mathrm{d}$ & $\mathrm{b}$ & \\
\hline Sinorhizobium terangae DSM $11282^{\mathrm{T}}$ & a & a & a & $\mathrm{d}$ & $\mathrm{w}$ & $\mathrm{e}$ & $\mathrm{w}$ & \\
\hline Sinorhizobium saheli DSM $11273^{\mathrm{T}}$ & a & a & $\mathrm{a}$ & $\mathrm{d}$ & $\mathrm{w}$ & $\mathrm{w}$ & $\mathrm{w}$ & \\
\hline
\end{tabular}

*Different restriction patterns were indicated with different letters for each endonuclease used. Designation of the restriction patterns is (if possible) in accordance with that used by Laguerre et al. (1994).

†The $16 \mathrm{~S}$ rDNA genotypes resulted from the combination of the seven restriction patterns of each strain tested. Only genotypes found among the isolates are shown.

pseudoacacia clones. The rhizobial isolates did not show any differences in nodulation activity with respect to the various Rob. pseudoacacia clones in three independent tests. Most isolates formed three to five nodules per plantlet within the observation period. The highest numbers were detected for isolates Rob11, Rob12 and Rob25 (Table 1). Distinctly lower numbers were found on roots inoculated with the isolates Rob13 and Rob17. Significant differences of nodulation activity were revealed for Rob11 and Rob25, as compared to Rob13 and Rob17. The isolate with the lowest nodulation ability (Rob17) was obtained from the black locust clone ROKO, which originated from Hungary. On the one hand we found a low nodulation ability of Rob17 with all tested plant clones as well as a generally low ability of the ROKO clone to form nodules, but on the other hand there was no preference or increased nodulation ability of Rob17 with the ROKO clone. The growth rate, which is often referred to as a mean characteristic to distinguish rhizobial genera (Young, 1996), was estimated using incubation time. In our study, isolates formed colonies within $3-5 \mathrm{~d}$ and Rob17-Rob19 were distinguished by incubation times of less than $4 \mathrm{~d}$ (Table 1). Both the Rhizobium legum- inosarum and the Rhizobium tropici reference strains could be differentiated from Mesorbizobium after $4 \mathrm{~d}$ incubation time. Concerning the colony characteristics, all isolates were opaque but they differed in colour. All isolates except Rob11, Rob17 and Rob20 grew well on medium enriched with $\mathrm{NaCl}$ up to a concentration of $1 \%$. This is in contrast to the salt tolerance of the Mesorhizobium species investigated as well as that of $R h$. tropici. Only $R h$. leguminosarum showed a similar low salt tolerance. The $\mathrm{pH}$ growth optimum generally ranged from 5.5 to $8 \cdot 5$. However, two isolates (Rob11 and Rob20) were unable to grow at $\mathrm{pH} 5 \cdot 5$. All strains including the reference strains utilized D-raffinose as sole carbon source, whereas three isolates and the Mesorhizobium huakuii strain were unable to grow with inositol. In general, the isolates showed a low tolerance to antibiotics, but about $50 \%$ of isolates were resistant to nalidixic acid.

\section{RFLP analysis of amplified 16S rDNA}

The rDNA of all 17 isolates was amplified using the primers $\mathrm{rd} 1$ and $\mathrm{fd} 1$, resulting in a characteristic single band of about $1500 \mathrm{bp}$. Restriction analysis of the PCR 
Table 3. Band sizes within the restriction patterns for rhizobial strains isolated from black locust

\begin{tabular}{|c|c|c|c|c|c|c|c|c|c|c|}
\hline \multirow{2}{*}{$\begin{array}{l}\text { Restriction } \\
\text { enzyme }\end{array}$} & \multirow{2}{*}{$\begin{array}{c}\begin{array}{c}\text { Restriction } \\
\text { pattern }\end{array} \\
\mathrm{a}\end{array}$} & \multicolumn{8}{|c|}{ Size of restriction fragments $(b p)^{*}$} & \multirow{2}{*}{$\begin{array}{l}\begin{array}{c}\text { Corresponding } 16 \mathrm{~S} \text { rDNA } \\
\text { genotypes } \dagger\end{array} \\
\text { I, II }\end{array}$} \\
\hline & & 400 & 225 & 210 & 210 & 185 & 145 & 100 & & \\
\hline & $\mathrm{x}$ & $240+160$ & $\cdot$ & $\cdot$ & $\cdot$ & $\cdot$ & $\cdot$ & $\cdot$ & & III \\
\hline & $\mathrm{y}$ & $240+160$ & 160 & . & . & $\cdot$ & . & . & & IV \\
\hline & $\mathrm{c}$ & 370 & 160 & 280 & $\cdot$ & 200 & $\cdot$ & - & & V,VI,VII,VIII, IX \\
\hline \multirow[t]{5}{*}{$C f_{o} \mathrm{I}$} & $\mathrm{a}$ & 330 & 280 & 280 & 170 & 135 & 110 & 110 & 80 & I, III \\
\hline & $\mathrm{b}$ & $\cdot$ & $\cdot$ & $\cdot$ & $\cdot$ & - & $\cdot$ & $\cdot$ & $\cdot$ & II \\
\hline & $\mathrm{y}$ & . & $\cdot$ & . & $\cdot$ & 100 & . & . & . & IV \\
\hline & $\mathrm{d}$ & . & 450 & . & - & 140 & . & . & . & V, VI, VII \\
\hline & $\mathrm{g}$ & $\cdot$ & $\cdot$ & $\cdot$ & $\cdot$ & 140 & $\cdot$ & $\cdot$ & $\cdot$ & VIII, IX \\
\hline \multirow[t]{2}{*}{ HaeIII } & $\mathrm{a}$ & 490 & 280 & 240 & 180 & 180 & 85 & & & I, II, V, VI, VII, VIII, IX \\
\hline & $\mathrm{b}$ & $\cdot$ & $\cdot$ & 210 & $\cdot$ & $\cdot$ & $\cdot$ & & & III, IV \\
\hline \multirow[t]{5}{*}{ HinfI } & a & 1170 & - & 220 & 120 & & & & & $\mathrm{I}, \mathrm{II}$ \\
\hline & $\mathrm{b}$ & 1290 & - & $\cdot$ & - & & & & & III, IV \\
\hline & $\mathrm{d}$ & 690 & 490 & · & $\cdot$ & & & & & VI \\
\hline & $\mathrm{e}$ & $370+320$ & 490 & . & . & & & & & V, VII \\
\hline & g & $370+320$ & $290+200$ & $\cdot$ & $\cdot$ & & & & & VIII, IX \\
\hline \multirow[t]{6}{*}{ MspI } & $\mathrm{a}$ & 500 & 420 & 225 & 180 & 125 & - & - & & I, III \\
\hline & $\mathrm{b}$ & 660 & $\cdot$ & $\cdot$ & $\cdot$ & - & - & - & & II \\
\hline & $\mathrm{e}$ & $\cdot$ & 310 & $\cdot$ & $\cdot$ & $\cdot$ & 140 & - & & VII, IX \\
\hline & $\mathrm{j}$ & 250 & 310 & · & . & . & 140 & $110+85$ & & VIII \\
\hline & $\mathrm{x}$ & 370 & 310 & . & . & . & 140 & 110 & & $\mathrm{~V}, \mathrm{VI}$ \\
\hline & $\mathrm{y}$ & 660 & 310 & $\cdot$ & $\cdot$ & - & 140 & - & & IV \\
\hline \multirow[t]{4}{*}{ Sau3A } & $\mathrm{a}$ & 710 & 230 & 175 & 175 & 85 & & & & I, II \\
\hline & $\mathrm{b}$ & $\cdot$ & 175 & $\cdot$ & $\cdot$ & $\cdot$ & & & & III \\
\hline & $\mathrm{e}$ & 950 & $\cdot$ & . & - & . & & & & V, VI, VII, VIII, IX \\
\hline & $\mathrm{y}$ & 950 & 175 & $\cdot$ & - & $\cdot$ & & & & IV \\
\hline \multirow[t]{5}{*}{ ScrFI } & $\mathrm{a}$ & 440 & 350 & 180 & 180 & 120 & 110 & 85 & - & I \\
\hline & $\mathrm{b}$ & · & 500 & $\cdot$ & $\cdot$ & - & $\cdot$ & $\cdot$ & - & II \\
\hline & $\mathrm{c}$ & 385 & 310 & . & $\cdot$ & . & $\cdot$ & . & 120 & V, VI, VII, VIII, IX \\
\hline & $\mathrm{x}$ & $\cdot$ & 500 & · & - & - & 300 & · & - & III \\
\hline & $\mathrm{y}$ & 310 & 500 & . & - & - & 300 & . & 120 & IV \\
\hline
\end{tabular}

*Band sizes of restriction fragments as determined by electrophoresis. Dots represent fragment sizes identical to those of pattern a. Dashes indicate the absence of restriction fragments.

$\dagger$ The $16 \mathrm{~S}$ rDNA genotypes are as given in Table 2 .

products using seven endonucleases revealed two to six restriction patterns per enzyme (Table 2). DNA fragments smaller than $80 \mathrm{bp}$ were not properly resolved by electrophoresis and were therefore not used for the comparison of patterns. On average, 41 restriction fragments per $16 \mathrm{~S}$ rDNA genotype were used for the classification of isolates, and nine distinct $16 \mathrm{~S}$ rDNA genotypes, each comprising one to five isolates, were found. To differentiate the nine genotypes, at least two enzymes (MspI, HinfI) were required. Band sizes of restriction patterns are shown in Table 3 to provide an overview of the differences between the various restriction patterns. The reference strains used in this study were also classified by restriction analysis of $16 \mathrm{~S}$ rDNA (Table 2). Designation of the corresponding restriction patterns followed that used by Laguerre et al. (1994). Four of the $16 \mathrm{~S}$ rDNA genotypes obtained from the isolates were found among the type strains of the rhizobial species tested. Thus genotypes I, II, VII and VIII were identical to $R h$. leguminosarum, $R h$. tropici, Mesorhizobium loti and M. huakuii, respectively. However, genotype VIII was identical to both the $M$. huakuii type strain as well as to a M. loti strain. Moreover, the 16S rDNA genotypes of the other isolates were not identical to those of rhizobial species or strains analysed by Laguerre et al. (1994).

The reference strain LMG 4270 isolated from black locust in central Iowa showed the $16 \mathrm{~S}$ rDNA genotype $\mathrm{V}$, which was also found in 5 of the 17 isolates. To assess phylogenetic diversity of rhizobia isolated within an area where black locust is native, 18 strains isolated by Batzli et al. (1992) were investigated. In total, seven $16 \mathrm{~S}$ rDNA genotypes were found. Only two strains belonged to genotype $\mathrm{V}$, whereas nine strains were identical to 


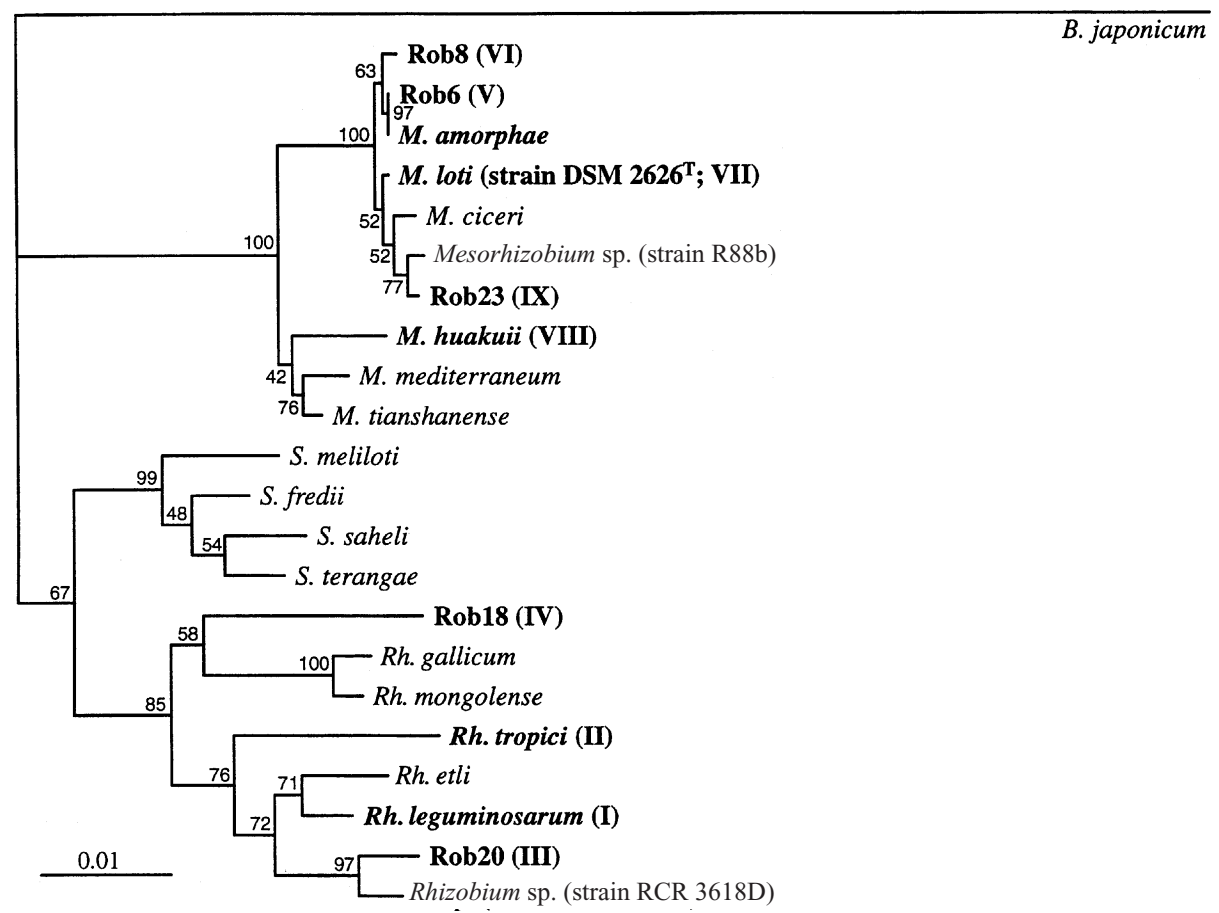

Fig. 1. Phylogenetic tree showing the relationships of the identified 165 rDNA genotypes of black-locust-nodulating isolates within rhizobia. The tree is based on a $1448 \mathrm{bp}$ alignment and was constructed using the neighbour-joining method (Saitou \& Nei, 1987). The values are numbers of times that a branch appeared in 100 bootstrap replications. Genotypes identified in this study are in bold characters. The bar indicates the relative sequence divergence. Representative sequences used for phylogenetic analysis: B. japonicum (accession no. U69638); M. amorphae (AF041445); M. ciceri (U07934); M. huakuii (D13431); M. loti DSM 2626 ${ }^{\top}$ (67229); Mesorhizobium sp. R88b (U50165); M. mediterraneum (L38825); M. tianshanense (AF041447); Sinorhizobium fredii (X67231); Rhizobium sp. RCR 36189 (U29387); Rh. etli (U28916); Rh. gallicum (U86343); Rh. leguminosarum bv. viciae (U29386); Rh. mongolense (U89822); Rh. tropici (U89832); Sinorhizobium meliloti (D14509); Sinorhizobium saheli (X68390); Sinorhizobium terangae (X68387).

genotype VIII and three strains to genotype IX. The other four genotypes were not found at the German location. Two genotypes were identical to Mesorhizobium tianshanense and a $M$. loti strain, whereas the remaining two genotypes were not found among the other strains investigated. In general, there were only a few differences between the seven genotypes identified from the strains from Maryland.

\section{DNA sequence analysis of isolates with unknown RFLP patterns}

$16 \mathrm{~S}$ rDNA sequencing was performed on a representative isolate of the genotypes that could not be classified by restriction analysis. All sequences showed a high homology to sequences from rhizobial species. The sequence of Rob6 (genotype V) was identical to that of Mesorhizobium amorphae. Best conformities of Rob8 (VI) and Rob23 (IX) were found with rDNA sequences of M. amorphae $(99.9 \%$ ) and the Mesorbizobium strain R88b (99.8\%), respectively. The $16 \mathrm{~S}$ rDNA sequences of Rob6 and Rob8 differed only in two nucleotides, but both genotypes were differentiated by RFLP analysis, illustrating the high resolution of this technique.

With respect to their restriction patterns, genotypes III and IV were more distinct in comparison to genotypes
V-IX (Tables 2 and 3). These differences were also demonstrated by the similarity of $16 \mathrm{~S}$ rDNA sequences; thus genotypes III and IV (Rob20 and Rob18) showed a similarity of $91.1 \%$ and $91.9 \%$, respectively, to genotype $\mathrm{V}$ (Rob6). The search for homologous sequences for Rob20 and for Rob18 resulted in a similarity index of $98 \cdot 1 \%$ to a Rhizobium strain nodulating Phaseolus vulgaris (RCR 3618D) and of $96.4 \%$ to Rhizobium gallicum, respectively.

An unrooted phylogenetic tree including further rhizobial species was constructed to illustrate the phylogenetic position of the identified genotypes (Fig. 1). As a result, isolates of groups V, VI, VII, VIII and IX were assigned to the genus Mesorhizobium (bootstrap values of $100 \%$ ). These genotypes represent $76 \%$ of the isolates. The isolates Rob6 and Rob8 were unequivocally clustered with $M$. amorphae. Furthermore, the phylogenetic tree showed the strong similarity of isolate Rob23 and Mesorhizobium strain R88b. Like the M. loti type strain, this strain was isolated from Lotus corniculatus. The isolate Rob18 branched with the $R h$. gallicum/Rhizobium mongolense grouping with a relatively low similarity and weak bootstrap support $(58 \%)$. Therefore, phylogenetic assignment of this isolate remains open. There is a good support $(97 \%)$ for the branching of Rob20 with the Rhizobium sp. strain 
RCR 3618D. Both isolates form a branch together with Rh. leguminosarum/Rhizobium etli $(72 \%$ bootstrap support).

\section{DISCUSSION}

It seems to be common that rhizobial isolates are capable of nodulating more than one legume species and several legume species can be nodulated by more than one rhizobial species (Young, 1996). Thus until recently, rhizobia able to nodulate $P$. vulgaris were assigned to $R h$. leguminosarum bv. phaseoli. However, at present, at least five species $(R h$. leguminosarum bv. phaseoli, $R h$. tropici, Rh. etli, Rh. gallicum and Rhizobium giardinii) can be distinguished based on both the organization of the symbiotic plasmid and sequence divergence of the $16 \mathrm{~S}$ rRNA gene (Amarger et al., 1997; Segovia et al., 1993; Martinez-Romero et al., 1991). Likewise, various other legumes were able to form nodules with different rhizobial species (Lafay \& Burdon, 1998; Perret et al., 2000). In our study, 17 rhizobial isolates were differentiated into nine $16 \mathrm{~S}$ rDNA genotypes. Most of the isolates $(76 \%)$ were classified in the genus Mesorbizobium (genotypes V-IX). The other genotypes (I-IV) assigned to the genus Rhizobium each consisted of only one isolate and showed a low relatedness to each other. Both genera belong to different evolutionary branches (Fig. 1; Jarvis et al., 1997), which is also shown by several phenotypic and genetic traits such as growth rate, fatty acid composition or similarity of nod genes (Jarvis et al., 1996; Haukka et al., 1998). Hence, isolates nodulating black locust represent a phylogenetically wide range of rhizobial species. Previous studies indicated that Rob. pseudoacacia can be nodulated by rhizobial strains obtained from nodules of Vicia, Trifolium, Lathyrus, Melilotus and Medicago species (Lyr, 1992; Hoffmann, 1964). With respect to the 160 legume species tested by Wilson (1939), Rob. pseudoacacia, along with another tree, had the broadest capacity to nodulate. Only some strains originally isolated from black locust were further investigated and the strain which was most effective in terms of nodulation and nitrogen fixation was classified as M. loti (Röhm \& Werner, 1992; Schäfer \& Werner, 1993). However, phylogenetic studies of indigenous rhizobia nodulating black locust have not been done previously. Comparing the phylogenetic diversity of our isolates with that of the strains obtained by Batzli et al. (1992) from an area where Rob.pseudoacacia is native revealed some similarities. Among the 18 strains tested, seven genotypes could be identified with four genotypes identical to the isolates from the German location. However, as shown by the similarity of the restriction patterns, all strains which originated from the native area, including the reference strain LMG 4270, can be assigned to the genus Mesorhizobium. Therefore, genetic diversity of the strains nodulating black locust seems to be higher at the German location. Whereas the genotype identical to $M$. amorphae dominated within the strains obtained from the German location, the dominance of a genotype identical to $M$. huakuii was found among the strains from the native location. Summarizing data from both locations, Rob. pseudoacacia was nodulated with various genomic species, most of which belong to the genus Mesorhizobium. Furthermore, $16 \mathrm{~S}$ rDNA sequences indicate some classification at the species level; however, additional studies involving DNA-DNA hybridization as well as phenotypic characterization would be necessary to confirm species assignment (Sullivan et al., 1996; Stackebrandt \& Goebel, 1994; Wayne et al., 1987).

Rob. pseudoacacia was introduced into middle Europe approximately 300 years ago. Although native only to the eastern USA, the tree species is now naturalized and widely planted throughout the world from temperate to subtropical areas. The rhizobia nodulating Rob.pseudoacacia are usually effective for nitrogen fixation as indicated by the red colour of the nodules or shown by their symbiotic host response (Batzli et al., 1992). It may be possible that some rhizobia were seed-borne and introduced together with the neophytic plant, as has been suggested for the transmission of $R h$. etli on seeds of $P$. vulgaris (Pérez-Ramirez et al., 1998). However, both the high phylogenetic diversity of isolates effective with Rob. pseudoacacia and its broad nodulation capacity support the view that indigenous rhizobia may be associated with this tree species. On the other hand, about half of the $16 \mathrm{~S}$ rDNA genotypes were identical at both locations and, as shown for L. corniculatus, symbiotic gene transfer could also cause diversity of nodulating strains (Sullivan et al., 1996). The highest proportion of the isolates obtained from the German location ( $47 \%$, genotypes $\mathrm{V}$ and $\mathrm{VI})$ showed identical or closely related $(99 \cdot 9 \%)$ ) $16 \mathrm{~S}$ rDNA sequences to $M$. amorphae. In general, we found a parallel picture of phylogenetic diversity of isolates nodulating Rob. pseudoacacia to those nodulating Amorpha fruticosa (Wang et al., 1999). Wang et al. (1999) analysed 55 isolates and identified five $16 \mathrm{~S}$ rDNA genotypes. The highest proportion of the isolates were M. amorphae, whilst two other genotypes belonging to the genus Mesorbizobium as well as some isolates related to $R h$. leguminosarum and Bradyrhizobium elkanii were also identified. Similar to Rob. pseudoacacia, A. fruticosa is a neophytic plant native to south-eastern and midWestern USA and was introduced into Asia more than 50 years ago. We suggest that neophytic and other legumes, especially when widely distributed, are less specific and form nodules with several phylogenetically different rhizobia, whereas archaeophytic plants could preferably host a singular or few specialist microsymbionts. A narrow host range of rhizobial strains is considered a specialization which developed for certain plants in restricted niches (Perret et al., 2000). However, further studies are necessary to evaluate this hypothesis.

The phylogenetic classification was mostly supported by phenotypic characteristics. Thus isolates classified in the genus Mesorhizobium generally showed a longer incubation time than the Rhizobium isolates (Rob17Rob20). The growth rates of the reference strains used in the study are in the same range, although there were 
some differences from the incubation time given by Jarvis et al. (1997). These authors showed an incubation time of $7 \mathrm{~d}$ for M. loti and of 5-6 d for M. huakuii. The markedly low salt tolerance of the isolates differed from the salt tolerance of the reference strains. However, our isolates were similar to all rhizobial groups isolated from $A$. fruticosa in that they did not grow at salt concentrations above $1 \% \mathrm{NaCl}$ (Wang et al., 1999). The phenotypic characters tested indicate a diversity of black-locust-nodulating rhizobia as already described by Batzli et al. (1992) for the rhizobial strains used as reference strains in this study. These strains demonstrated a high heterogeneity of several phenotypic characters, including carbohydrate utilization, nitrogen fixation, generation times between 3 and $9 \mathrm{~h}$ and different protein profiles. As shown for the phylogenetic diversity, there was a similar phenotypic heterogeneity of strains to those reported for rhizobia nodulating the leguminous shrub A. fruticosa.

Our results revealed a high phylogenetic diversity with seven genotypes among 17 isolates analysed, which suggests the existence of further taxa nodulating Rob. pseudoacacia. The high phenotypic and phylogenetic diversity of rhizobial strains obtained from black locust seems to be characteristic for widely distributed legumes. This could enhance their ability to spread into new areas. Thus rhizobial diversity is considered to be a reason for the success of black locust as a pioneer tree species outside its native range and the suitability of the tree for natural succession on former arable land and recultivation areas under temperate conditions.

\section{ACKNOWLEDGEMENTS}

This work was supported by the Federal Ministry of Food, Agriculture and Forestry (BML) and the Ministry of Food, Agriculture and Forestry of the State of Brandenburg (MELF).

We thank Peter van Berkum and Douglas K. Jones for kindly providing rhizobial strains isolated from black locust in Maryland. We are grateful to Mrs Eva Riedel, Mrs Renate Rietz and Mrs Sigune Weinert for technical assistance.

\section{REFERENCES}

Amarger, N., Bours, M., Revoy, F., Allard, R. \& Laguerre, G. (1994). Rhizobium tropici nodulates field-grown Phaseolus vulgaris in France. Plant Soil 161, 147-156.

Amarger, N., Macheret, V. \& Laguerre, G. (1997). Rhizobium gallicum sp. nov. and Rhizobium giardinii sp. nov. from Phaseolus vulgaris nodules. Int J Syst Bacteriol 47, 996-1006.

Arnold, W. \& Pühler, A. (1988). A family of high-copy-number plasmid vectors with single end-label sites for rapid nucleotide sequencing. Gene 70, 171-179.

Balla, I., Vertesy, J., Koves-Pechy, K., Voros, I., Bujtas, Z. \& Biro, B. (1998). Acclimation results of micropropagated black locust (Robinia pseudoacacia L.) improved by symbiotic microorganisms. Plant Cell Tissue Organ Cult 52, 113-115.

Batzli, J. M., Graves, W. R. \& van Berkum, P. (1992). Diversity among rhizobia effective with Robinia pseudoacacia L. Appl Environ Microbiol 58, 2137-2143.

Chen, W. X., Yan, G. H. \& Li, J. L. (1988). Numerical taxonomic study of fast-growing soybean rhizobia and a proposal that
Rhizobium fredii be assigned to Sinorhizobium gen. nov. Int J Syst Bacteriol 38, 392-397.

Cilia, V., Lafay, B. \& Christen, R. (1996). Sequence heterogeneities among 16S ribosomal RNA sequences, and their effect on phylogenetic analyses at the species level. Mol Biol Evol 13, 451-461.

Dreyfus, B., Garcia, J. L. \& Gillis, M. (1988). Characterization of Azorhizobium caulinodans gen. nov., sp. nov., a stem-nodulating nitogen-fixing bacterium isolated from Sesbania rostrata. Int J Syst Bacteriol 38, 89-98.

Elkan, G. H. \& Bunn, C. R. (1992). The rhizobia. In The Prokaryotes: a Handbook on the Biology of Bacteria - Ecophysiology, Isolation, Identification, Applications, pp. 21972210. Edited by A. Balows, H. G. Trüper, M. Dworkin, W. Harder \& K. H. Schleifer. New York: Springer.

Felsenstein, J. (1993). PHYLIP (phylogeny interference package), 3.5 c edition. University of Washington, Seattle, USA.

Fox, R. T. V. (1993). Principles of Diagnostic Techniques in Plant Pathology. Wallingford, UK: CAB International.

Gruber, K. F. \& Hanover, J. W. (1992). An effective protocol for large scale micropropagation of black locust (Robinia pseudoacacia). In Black Locust: Biology, Culture, and Utilization, pp. 126-135. Edited by J. W. Hanover, K. Miller \& S. Plesko. East Lansing: Michigan State University Press.

Han, S. F. (1996). Screening efficient strains of locust (Robinia pseudoacacia) nodule bacteria. I Nanjing Forestry Univ 20, 73-76.

Hanover, J. W. (1992). Black locust: a historical and future perspective. In Black Locust: Biology, Culture, and Utilization, pp. 7-18. Edited by J. W. Hanover, K. Miller \& S. Plesko. East Lansing: Michigan State University Press.

Haukka, K., Lindström, K. \& Young, J.P. W. (1998). Three phylogenetic groups of nodA and nifH genes in Sinorhizobium and Mesorhizobium isolates from leguminous trees growing in Africa and Latin America. Appl Environ Microbiol 64, 419-426.

Herrera, M. A., Salamanca, C. P. \& Barea, J. M. (1993). Inoculation of woody legumes with selected arbuscular mycorrhizal fungi and rhizobia to recover desertified Mediterranean ecosystems. Appl Environ Microbiol 59, 129-133.

Hoffmann, G. (1964). Effektivität und Wirtsspezifität der Knöllchenbakterien von Robinia pseudoacacia L. Arch Forstwesen 13, 563-576.

Jarvis, B. D. W., Sivakumaran, S., Tighe, S. W. \& Gillis, M. (1996). Identification of Agrobacterium and Rhizobium species based on cellular fatty acid composition. Plant Soil 184, 143-158.

Jarvis, B. D. W., van Berkum, P., Chen, W. X., Nour, S. M., Fernandez, M. P., Cleyet-Marel, J. C. \& Gillis, M. (1997). Transfer of Rhizobium loti, Rhizobium huakuii, Rhizobium ciceri, Rhizobium mediterraneum, and Rhizobium tianshanense to Mesorhizobium gen. nov. Int J Syst Bacteriol 47, 895-898.

Jordan, D. C. (1982). Transfer of Rhizobium japonicum Buchanan 1980 to Bradyrhizobium gen. nov., a genus of slow-growing, root nodule bacteria from leguminous plants. Int J Syst Bacteriol 32, 136-139.

Kimura, M. (1980). A simple method for estimating evolutionary rates of base substitutions through comparative studies of nucleotide sequences. J Mol Evol 16, 111-120.

Lafay, B. \& Burdon, J. J. (1998). Molecular diversity of rhizobia occurring on native shrubby legumes in southeastern Australia. Appl Environ Microbiol 64, 3989-3997.

Laguerre, G., Fernandez, M. P., Edel, V., Normand, P. \& Amarger, N. (1993). Genomic heterogeneity among French Rhizobium 
strains isolated from Phaseolus vulgaris L. Int J Syst Bacteriol 43, 761-767.

Laguerre, G., Allard, M. R., Revoy, F. \& Amarger, N. (1994). Rapid identification of rhizobia by restriction fragment length polymorphism analysis of PCR-amplified $16 \mathrm{~S}$ rRNA genes. Appl Environ Microbiol 60, 56-63.

de Lajudie, P., Willems, A., Pot, B. \& 7 other authors (1994). Polyphasic taxonomy of rhizobia: emendation of the genus Sinorhizobium and description of Sinorhizobium meliloti comb. nov., Sinorhizobium saheli comb. nov., and Sinorhizobium teranga sp. nov. Int J Syst Bacteriol 44, 715-733.

Lyr, H. (1992). Die $\mathrm{N}_{2}$-Bindung durch Leguminosen. In Physiologie und Ökologie der Gehölze, pp. 133-135. Edited by H. Lyr, H. J. Fiedler \& W. Tranquillini. Jena: Fischer.

Martinez-Romero, E., Segovia, L., Mercante, F. M., Franco, A. A., Graham, P. \& Pardo, M. A. (1991). Rhizobium tropici, a novel species nodulating Phaseolus vulgaris L. beans and Leucaena sp. trees. Int J Syst Bacteriol 41, 417-426.

Pérez-Ramirez, N. O., Rogel-Hernández, M. A., Wang, E. T. \& Martinez-Romero, E. (1998). Seeds of Phaseolus vulgaris bean carry Rhizobium etli. FEMS Microbiol Ecol 26, 289-296.

Perret, X., Staehelin, C. \& Broughton, W. J. (2000). Molecular basis of symbiotic promiscuity. Microbiol Mol Biol Rev 64, 180-201.

Qian, D., Allen, F. L., Stacey, G. \& Gresshoff, P. M. (1996). Plant genetic study of restricted nodulation in soybean. Crop Sci 36, 243-249.

Röhm, M. \& Werner, D. (1992). Robinia pseudoacacia-Rhizobium symbiosis: isolation and characterization of a fast nodulating and efficiently nitrogen fixing Rhizobium strain. Nitrogen Fixing Tree Res Reports 10, 193-197.

Saitou, N. \& Nei, M. (1987). The neighbor-joining method: a new method for reconstructing phylogenetic trees. Mol Biol Evol 4, 406-425.

Schäfer, B. \& Werner, D. (1993). Nodulation of Robinia pseudoacacia by two Rhizobium strains. Nitrogen Fixing Tree Res Rep $11,121-126$.

Segovia, L., Young, J.P. W. \& Martinez-Romero, E. (1993). Reclassification of American Rhizobium leguminosarum biovar phaseoli type I strains as Rhizobium etli sp. nov. Int J Syst Bacteriol 43, 374-377.

Stackebrandt, E. \& Goebel, B. M. (1994). Taxonomic note: a place for DNA-DNA reassociation and $16 \mathrm{~S}$ rRNA sequence analysis in the present species definition in bacteriology. Int J Syst Bacteriol 44, 846-849.

Sullivan, J. T., Eardly, B. D., van Berkum, P. \& Ronson, C. W. (1996). Four unnamed species of nonsymbiotic rhizobia isolated from the rhizosphere of Lotus corniculatus. Appl Environ Microbiol 62, 2818-2825.

Thompson, J. D., Higgins, D. G. \& Gibson, T. J. (1994). CLUSTAL W : improving the sensitivity of progressive multiple sequence alignment through sequence weighting, positions-specific gap penalties and weight matrix choice. Nucleic Acids Res 22, 4673-4680.

Thorne, D. W. \& Walker, R. H. (1936). The influence of seed inoculation upon the growth of black locust seedlings. J Am Soc Agron 28, 28-34.

Ulrich, A. \& Müller, T. (1998). Heterogeneity of plant-associated streptococci as characterised by phenotypic features and restriction analysis of PCR-amplified $16 \mathrm{~S}$ rDNA. J Appl Microbiol 84, 293-303.

Wang, E. T., van Berkum, P., Sui, X. H., Beyene, D., Chen, W. X. \& Martinez-Romero, E. (1999). Diversity of rhizobia associated with Amorpha fruticosa isolated from Chinese soils and description of Mesorhizobium amorphae sp. nov. Int J Syst Bacteriol 49, 51-65.

Wayne, L. G., Brenner, D. J., Colwell, R. R. \& 9 other authors (1987). Report of the ad hoc committee on reconciliation of approaches to bacterial systematics. Int J Syst Bacteriol 37, 463-464.

Weisburg, W. G., Barns, S. M., Pelletier, D. A. \& Lane, D. J. (1991). $16 \mathrm{~S}$ ribosomal DNA amplification for phylogenetic study. $J$ Bacteriol 173, 697-703.

Wilson, J. K. (1939). Leguminous Plants and their Associated Organisms. Cornell University Agricultural Experiment Station memoir 221. Ithaca, NY: Cornell University Press.

Woese, C. R. (1987). Bacterial evolution. Microbiol Rev 51, 221-271.

Young, J. P. W. (1996). Phylogeny and taxonomy of rhizobia. Plant Soil 186, 45-52.

Young, J. P. W. \& Haukka, K. E. (1996). Diversity and phylogeny of rhizobia. New Phytol 133, 87-94.

Received 28 February 2000; revised 8 June 2000; accepted 9 August 2000. 